\title{
CHARGE CARRIER TRANSPORT PROPERTIES IN TERNARY Si-PCPDTBT:P3HT:PCBM SOLAR CELLS
}

\author{
J. Važgèla, M. Stephen, G. Juška, K. Genevičius, and K. Arlauskas \\ Department of Solid State Electronics, Vilnius University, Sauletekio 9, LT-10222 Vilnius, Lithuania \\ E-mail: julius.vazgela@ff.vu.lt
}

Received 20 September 2016; revised 3 November 2016; accepted 21 December 2016

\begin{abstract}
In this work we investigate ternary blends of an active layer in bulk heterojunction solar cells and estimate the influence of their composition on solar cell parameters such as efficiency, mobility and recombination. The studied ternary blends are composed of low bandgap polymer poly[2,6-(4,4-bis(2-ethylhexyl)dithieno[3,2-b:2,3-d]silole)-alt-4,7-(2,1,3 benzothiadiazole)] (Si-PCPDTBT), high bandgap polymer poly(3-hexylthiophene-2,5-diyl) (P3HT) and fullerene derivative [6,6]-phenyl-C ${ }_{61}$-butyric acid methyl ester (PCBM). The Langevin recombination reduction factor as well as charge carrier mobilities show an increasing trend with increasing Si-PCPDTBT content in the blends. The highest efficiencies have been achieved for the optimized blends of Si-PCPDTBT:P3HT:PCBM with ratios of 0.4:0.6:1, respectively.
\end{abstract}

Keywords: TOF, organic solar cells, bimolecular recombination, Si-PCPDTBT

PACS: $73.50 . \mathrm{Gr}$, 73.61.Ph, 73.61.Wp

\section{Introduction}

Due to the simple solution processing, organic semiconductors are promising materials for applications of solar cells. During the last five years, the performance of organic bulk heterojunction (BHJ) solar cells has improved considerably [1], 2]. Light absorption in $\mathrm{BHJ}$, separation of photogenerated charge carriers, their recombination and collection at the electrodes determine solar cell's efficiency. Bimolecular recombination in low mobility disordered organic materials is expected to follow the Lagevin's theory which predicts a recombination rate directly proportional to the mobility of charge carriers. The rate of recombination is determined by the probability for electrons and holes to meet in space, given by the equation

$$
\beta=\frac{\xi_{e}\left(\mu_{\mathrm{n}}+\mu_{\mathrm{p}}\right)}{\varepsilon \varepsilon_{0}},
$$

where $\xi$ is the Langevin recombination reduction factor, $\xi=1$ in the case of pure Langevin recombination and $\xi<1$ if the recombination is reduced, $e$ is the elementary charge, $\mu_{\mathrm{n}}\left(\mu_{\mathrm{p}}\right)$ is the electron (hole) mobility, and $\varepsilon\left(\varepsilon_{0}\right)$ is the relative (absolute) dielectric permittivity. Most $\mathrm{BHJ}$ solar cells exhibit the Langevin-like recombination $(\xi \approx 1)$. However, few blends, like the widely studied P3HT:PCBM (poly(3-hexylthiophene-2,5-diyl):[6,6]-phenyl- $\mathrm{C}_{61}$-butyric acid methyl ester), exhibit a highly reduced Langevin recombination $(\xi \ll 1)$, which is considered a pre-requisite to relatively thick active layers ( $>200 \mathrm{~nm})$. Due to bimolecular recombination losses, the thickness of most high efficiency organic solar cells is confined to 60$110 \mathrm{~nm}$, which limits the light absorption and hence the short circuit current [3, 4]. Moreover, thicker active layers are generally desirable for industrially relevant bulk processing techniques, like roll-to-roll printing. Typically, annealed P3HT:PCBM solar cells exhibit strongly reduced Langevin recombination owing to their highly ordered morphology [5]. Ternary blends consisting of two donor moieties and one acceptor are a stimulating concept in order to enhance the optical absorption and spectral sensitivity of active layer blends [6]. The morphology of the resulting system and hence the bimolecular recombination losses largely affect the photovoltaic performance of such systems [河. Unlike the P3HT:PCBM system, the majority of low bandgap polymers exhibit the Langevin type recombination when blended with PCBM [8]. Therefore, while the addition of low bandgap polymers to the $\mathrm{P} 3 \mathrm{HT}$ :PCBM system improves 
the absorption, it can also disrupt the highly ordered morphology of P3HT:PCBM blend. In this work we use the low bandgap polymer poly[2,6-(4,4-bis(2ethylhexyl)dithieno[3,2-b:2,3-d] silole)-alt-4,7-(2,1,3 benzothiadiazole)] (Si-PCPDTBT) to provide ternary blends of Si-PCPDTBT:P3HT:PCBM with improved light absorption. Figure 1 shows the chemical structures of molecules used in this study. Furthermore, we discuss the trend of power conversion efficiency (PCE) and the Langevin recombination reduction factor in $\mathrm{BHJ}$ cells with varying compositions of $\mathrm{Si}$ PCPDTBT:P3HT:PCBM.

(a)

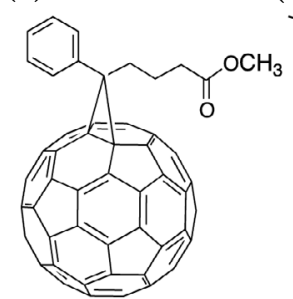

(b)

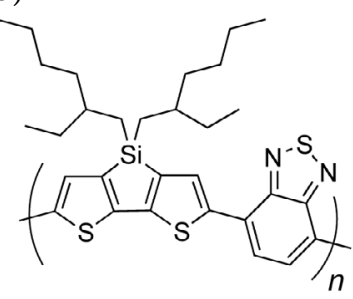

(c)

Fig. 1. Molecular structures of (a) Si-PCPDTBT, (b) P3HT and (c) PCBM.

\section{Materials and experimental methods}

The samples used in this study were made on glass substrates coated with indium tin oxide (ITO), by spin coating a $50 \mathrm{~nm}$ thick layer of PEDOT:PSS followed by a $100 \mathrm{~nm}$ thick active layer and evaporating a $100 \mathrm{~nm}$ thick Al top contact. Active layers were deposited with varying ratios of $0: 1: 1,0.2: 0.8: 1,0.4: 0.6: 1$ and 0.8:0.2:1, respectively, for Si-PCPDTBT:P3HT:PCBM. The active area of the device was $0.13 \mathrm{~cm}^{2}$. The devices were exposed to AM1.5 from a Newport 94082A Solar Simulator and data was collected using a sourcemeter (Keithley 2400).

The extraction of photogenerated charge carriers by linearly increasing voltage (photo-CELIV) measurements was performed using a pulsed second-harmonic $532 \mathrm{~nm}$ Nd:YAG laser (EKSPLA PL2143), an oscilloscope (Tektronix DPO4054B) and a generator (Tektronix AFG3022B) with load resistance of $50 \Omega$ and voltage ramp of $10^{5} \mathrm{~V} / \mathrm{s}$. The duration of the laser pulse was 30 ps with the beam diameter of $6 \mathrm{~mm}$ and the sample was illuminated from the ITO side. At $532 \mathrm{~nm}$ the absorption coefficient $\alpha$ of the samples was from $6.4 \times 10^{4} \mathrm{~cm}^{-1}$ to $1.05 \times 10^{5} \mathrm{~cm}^{-1}$, giving $\alpha d$ from 0.64 to 1.05 which means bulk photogeneration, where $d$ is the thickness of an active layer. The laser was synchronized with a triangle voltage pulse generator. Photogenerated charge carriers were extracted after a certain delay time by employment of the reverse polarity triangle voltage pulse. Low light intensities were used for photo-CELIV measurements so that the condition of the low conductivity regime is fulfilled $\left(\Delta j<j_{0}\right)$, and the mobilities were estimated using the equation that considers the volume photogeneration [9]

$$
\mu=\frac{2 d^{2}}{3 A t_{\max }^{2}}
$$

where $A=\mathrm{d} U / \mathrm{d} t$ is the voltage ramp, $t_{\max }$ is the maximum of current transient, $j_{0}$ is the initial step of the current transient, $\Delta j$ is the difference between the current transient's maximum $j_{\max }$ and $j_{0}$ (refer to Fig. 2).

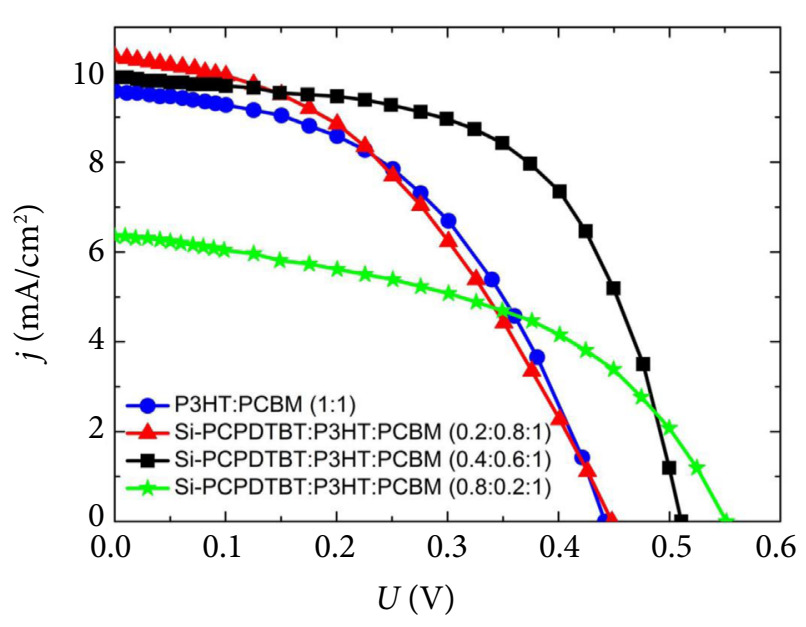

Fig. 2. Current-voltage characteristics of P3HT:PCBM (blue circles online) and representative ternary Si:PCPDTBT:P3HT:PCBM solar cells, with corresponding ratios of 0.2:0.8:1 (red triangles), 0.4:0.6:1 (black squares) and 0.8:0.2:1 (green stars) under illumination of AM1.5 spectra.

The same equipment as in the photo-CELIV technique was used for time-of-flight (TOF) experiments. The reverse polarity square voltage pulse was applied to the contacts and the sample was excited by a short laser pulse. TOF measurements were made in the integral mode TOF $\left(\tau_{R C} \gg t_{\mathrm{tr}}\right.$, where $\tau_{R C}$ is the time constant of the setup, $t_{\text {tr }}$ is the charge carrier transit time, $t_{\mathrm{tr}}=d^{2} / \mu U$, $U$ is the applied voltage). Using this technique, the Langevin recombination reduction factor $\xi$ could be estimated as described in Ref. [7]:

$$
\xi=\frac{\beta}{\beta_{\mathrm{L}}}=\frac{C U}{Q_{\mathrm{e}}} \frac{t_{\mathrm{tr}}}{t_{\mathrm{e}}} .
$$

Here $C$ is the capacitance of the sample, $Q_{\mathrm{e}}$ is the extracted charge that is equal to the integral of current transient, $t_{\mathrm{e}}$ is the extraction time, $t_{\mathrm{e}}=t_{1 / 2}\left(L_{\mathrm{Q}_{\mathrm{g}} \gg C U}\right)-$ 
$t_{1 / 2}\left(L_{Q_{g} \ll C U}\right)$ (refer to Fig. A). $t_{1 / 2}$ is the time at which the current transient reduces to the half of its maximum value, $t_{1 / 2}\left(L_{Q_{\mathrm{g}} \gg C U}\right)$ is $t_{1 / 2}$ at high light intensity $L$ where the photogenerated charge $Q_{\mathrm{g}}$ is much higher than the charge stored on the contacts $C U$, and $t_{1 / 2}\left(L_{Q_{\mathrm{g}} \ll C U}\right)$ is the $t_{1 / 2}$ at low light intensity where the photogenerated charge $Q_{\mathrm{g}}$ is much lower than the charge stored on the contacts $C U$. The condition of $t_{1 / 2}\left(L_{Q_{\mathrm{g}} \gg C U}\right)$ is obtained when the input light intensity is high enough to saturate the TOF current transient, creating a reservoir of photogenerated charges.

\section{Results and discussion}

Figure 3 shows the current-voltage characteristics of solar cell devices consisting of active layers of different compositions of Si-PCPDTBT:P3HT:PCBM. The open-circuit voltage $\left(V_{\text {oc }}\right)$, the short circuit current density $\left(J_{\mathrm{sc}}\right)$ and the calculated fill factor $(\mathrm{FF})$ together with the power conversion efficiency (PCE) are presented in Table 1. Maximum efficiencies were obtained from the blends consisting of the $40 \%$ donor loading of Si-PCPDTBT, i. e. a ratio of 0.4:0.6:1 for Si-PCPDTBT:P3HT:PCBM, respectively. An increase in $V_{o c}$ is observed with increasing the $\mathrm{Si}$ PCPDTBT content of the blends, which could be originating from the lower lying HOMO levels of $\mathrm{Si}$ PCPDTBT with respect to P3HT [10]. Such a trend of increasing open circuit voltages has been reported in analogous ternary blends consisting of $\mathrm{Si}$ PCPDTBT [8]. The short circuit currents are found to increase initially with the $20 \%$ donor loading of $\mathrm{Si}$-PCPDTBT, i. e. a ratio of $0.2: 0.8: 1$, respectively, for Si-PCPDTBT:P3HT:PCBM, which then reduces with a further increase in the Si-PCPDTBT content.

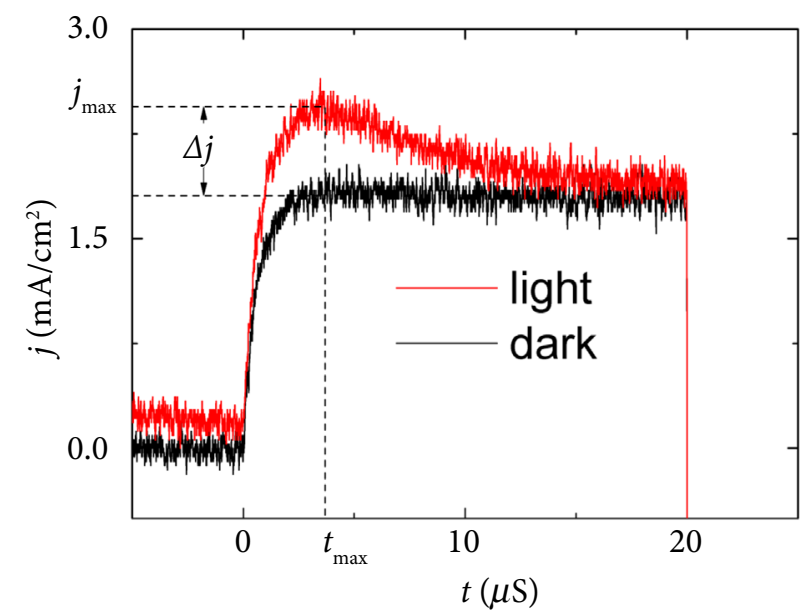

Fig. 3. Representative photo-CELIV current transients for P3HT:PCBM blend.
Table 1. Photovoltaic performance and photo-CELIV mobilities of Si-PCPDTBT:P3HT:PCBM solar cells with a varying composition.

\begin{tabular}{c|c|c|c|c|c}
\hline Blend & $\begin{array}{c}V_{\text {oc }} \\
\mathrm{mV}\end{array}$ & $\begin{array}{c}J_{\text {sc }} \\
\mathrm{mA} / \mathrm{cm}^{2}\end{array}$ & $\begin{array}{c}\mathrm{FF}, \\
\%\end{array}$ & $\begin{array}{c}\text { PCE, } \\
\%\end{array}$ & $\begin{array}{c}\mu, \\
10^{-5} \mathrm{~cm}^{2} / \mathrm{Vs}\end{array}$ \\
\hline $0: 1: 1$ & 440 & 9.55 & 48 & 1.6 & 5.3 \\
\hline $0.2: 0.8: 1$ & 450 & 10.33 & 42 & 1.5 & 6.5 \\
\hline $0.4: 0.6: 1$ & 510 & 9.85 & 59 & 2.3 & 6.8 \\
\hline $0.8: 0.2: 1$ & 550 & 6.34 & 47 & 1.3 & 20 \\
\hline
\end{tabular}

Furthermore, photo-CELIV transients were recorded to estimate the average charge carrier mobilities of the blends of different compositions. As previously discussed, the photo-CELIV measurements were carried out in the moderate conductivity regime (Fig. 2) and charge carrier mobilities calculated using Eq. (2) are included in Table 1. It has been acknowledged that the CELIV peak is influenced by both kinds of charge carriers and hence the average mobility is obtained. The photo-CELIV mobility appears to be enhanced in blends containing higher ratios of Si-PCPDTBT, with significantly improved mobilities obtained for the donor loading of $80 \% \mathrm{Si}$-PCPDTBT.

To study the bimolecular recombination in these blends, integral TOF measurements were carried out at high light intensities and the Langevin reduction factor $\xi$ was estimated in each of the samples using Eq. (3). Figure 4 shows the representative integral TOF transients and describes the estimation of the extraction time $t_{\mathrm{e}}$. The TOF transients are recorded at varying input light intensities until the transients saturate. This results in the formation of a reservoir of charge carriers forming a space charge region wherein

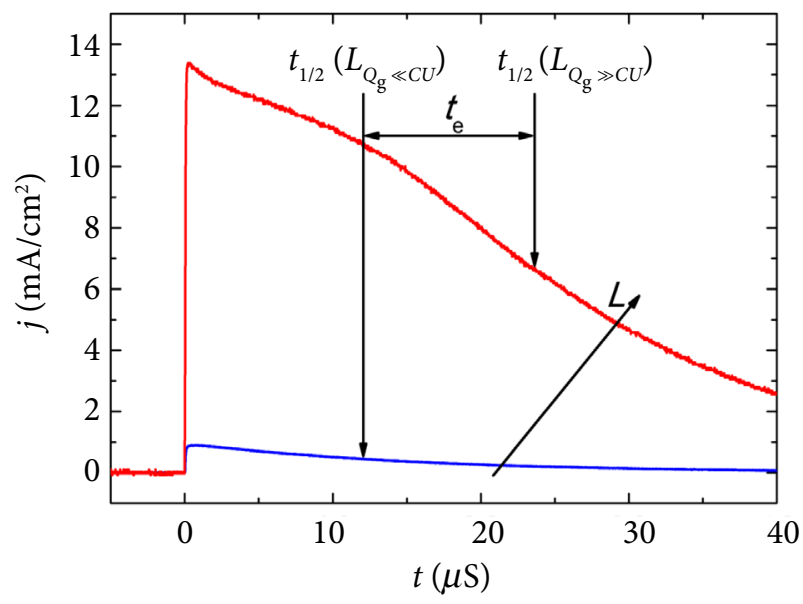

Fig. 4. Si-PCPDTBT:P3HT:PCBM 0.4:0.6:1 sample's TOF transients for $U=1.5 \mathrm{~V}, R=1 \mathrm{k} \Omega$ at low (blue line) and high (red line) light intensities. 
the built-in field is screened and the recombination becomes diffusion limited. If the dominant recombination is of a pure Langevin type, the photogenerated charges quickly recombine and the extracted charge remains equal to the charge stored on the contacts, $C U$, since $t_{1 / 2}\left(L_{Q_{\mathrm{g}} \gg C U}\right) \approx t_{1 / 2}\left(L_{Q_{\mathrm{g}} \ll C U}\right)$. If the recombination is strongly reduced, both $t_{1 / 2}\left(L_{Q_{g} \gg C U}\right)$ and the extracted charge $Q_{e}$ increase with light intensity until they ultimately saturate. This results in the condition $t_{1 / 2}\left(L_{Q_{\mathrm{g}} \gg \mathrm{CU}}\right)>t_{1 / 2}\left(L_{Q_{\mathrm{g}} \ll C U}\right)$, and the extracted charge $Q_{\mathrm{e}}$ becomes higher than $C U$.

This is evident in the transients shown in Fig. 4, which correspond to the blend containing a ratio of 0.4:0.6:1, respectively, for Si-PCPDTBT:P3HT:PCBM, where it can be clearly seen that $t_{1 / 2}\left(L_{\mathrm{Q}_{\mathrm{g}} \gg C U}\right)>t_{1 / 2}\left(L_{\mathrm{Q}_{\mathrm{g}} \ll \mathrm{CU}}\right)$, indicating the bimolecular recombination being reduced compared to the Langevin factor $(\xi<1)$.

However, in the case of bulk photogeneration ( $\alpha d \approx 1$, which is the case in this study) the value of the Langevin recombination reduction factor $\xi$, obtained from this technique, is acknowledged to be dependent on load resistance and is only approximate [ 11]. With increasing load resistance, photogenerated charge extraction from the sample takes longer, more charge carriers recombine and the extracted charge $Q_{e}$ decreases. The extraction time $t_{\mathrm{e}}$ was found to be more sensitive to load resistance than the extracted charge $Q_{e}$ which brings about possible inaccuracies in the obtained value 11]. To this end, Philippa et al. introduced the HI-RPV method to provide $\xi$ values independent of load resistance [12]. However, this method necessitates the precise knowledge of series resistance of the sample for the accurate estimation of Langevin reduction factor $\xi$. Hence we calculated the Langevin recombination reduction factor across the samples over a range of variable load resistances from 1 to $10 \mathrm{k} \Omega$, which is shown in Fig. 5. The knowledge of mobilities from photo-CELIV allowed us to calculate the transit times $\left(t_{\mathrm{tr}}=d^{2} / \mu U\right)$ used in these calculations.

It is evident that the obtained $\xi$ values are strongly resistance dependent, suggesting they are only approximate. Nonetheless, at a certain resistance, the Langevin reduction factor $\xi$ is found to increase with increasing the Si-PCPDTBT content, suggesting enhanced bimolecular recombination losses in the blends containing higher ratios of Si-PCPDTBT. Since the bimolecular recombination depends on the probability of charge carriers to meet in space, this trend could be originating from either the increased mobility of charge carriers or the formation of morphology with enhances the probability of charge carriers to meet. The former case of increased charge carrier mobilities is evidenced by photo-CELIV transients as discussed in the previous section. The morphology of the $\mathrm{BHJ}$ blend is known to

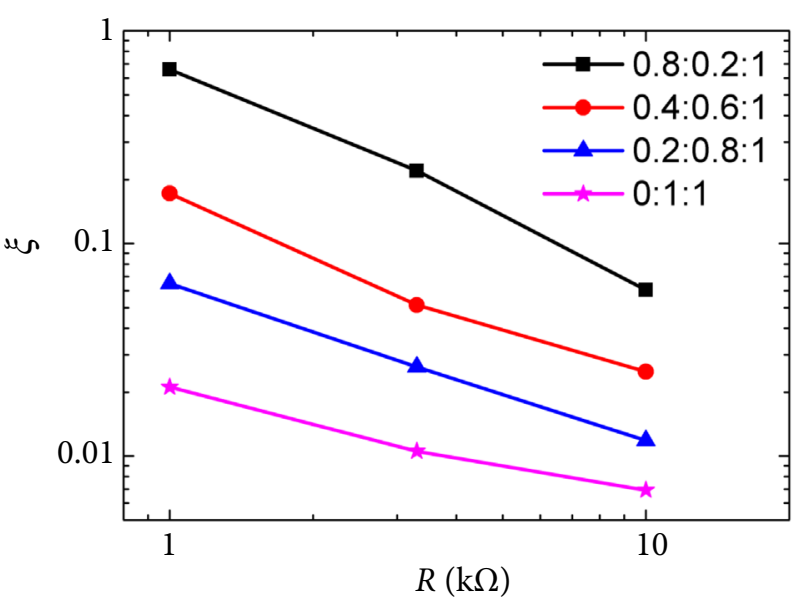

Fig. 5. Langevin recombination reduction factor $\xi$ dependence on load resistance in Si-PCPDTBT:P3HT: PCBM blends obtained by using integral TOF technique (black squares for 0:1:1, red circles for 0.4:0.6:1, blue triangles for 0.2:0.8:1 and purple stars for 0.8:0.2:1 structure, respectively).

be sensitive to its composition [13, 14] and hence both of the aforementioned cases are likely to be contributing to the observed trend of enhanced bimolecular recombination with increasing Si-PCPDTBT content.

\section{Conclusions}

The photovoltaic performance and charge transport parameters of ternary blends of Si-PCPDTBT: P3HT:PCBM with different compositions have been documented. While the open circuit voltage as well as the photo-CELIV mobility of charge carriers were found to be increasing with increasing Si-PCPDTBT content, the bimolecular recombination losses were also found to be enhanced in the blends with higher ratios of Si-PCPDTBT. Thus an interplay of several factors like frontier molecular energy levels, charge carrier mobilties and recombination are found to influence the photovoltaic performance and complementary studies are required to obtain a complete picture. The concept of ternary blends for $\mathrm{BHJ}$ is promising to push the efficiency limits of traditional two-component BHJs and needs to be explored further.

\section{Acknowledgements}

This research has received funding from the Research Council of Lithuania by Grant MIP-091/2015 and from the European Union Seventh Framework Program (FP7/2011) under Grant Agreement ESTABLIS No. 290022. 


\section{References}

[1] D.M.A. Green, K. Emery, Y. Hishikawa, W. Warta, and E.D. Dunlop, Solar cell efficiency tables (Version 47), Progr. Photovoltaics 24(7), 905-913 (2016), https://dx.doi.org/10.1002/pip.2788

[2] M.C. Scharber and N.S. Sariciftci, Efficiency of bulk-heterojunction organic solar cells, Progr. Polymer. Sci. 38, 1929-1940 (2013), https://dx.doi. org/10.1016/j.progpolymsci.2013.05.001

[3] S. Albrecht, S. Schäfer, I. Lange, S. Yilmaz, I. Dumsch, S. Allard, U. Scherf, A. Hertwig, and D. Neher, Light management in PCPDTBT:PC ${ }_{70} \mathrm{BM}$ solar cells: A comparison of standard and inverted device structures, Org. Electron. 13, 615-622 (2012), https://dx.doi.org/10.1016/j.orgel.2011.12.019

[4] J. Peet, L. Wen, P. Byrne, S. Rodman, K. Forberich, Y. Shao, N. Drolet, R. Gaudiana, G. Dennler, and D. Waller, Bulk heterojunction solar cells with thick active layers and high fill factors enabled by a bithiophene-co-thiazolothiazole push-pull copolymer, Appl. Phys. Lett. 98, 043301 (2011), https://dx.doi.org/10.1063/1.3544940

[5] G. Juška, K. Genevičius, N. Nekrašas, and G. Šliaužys, Two-dimensional Langevin recombination, Phys. Status Solidi C 7(3-4), 980-983 (2010), https://dx.doi.org/10.1002/pssc.200982660

[6] M. Koppe, H.-J. Egelhaaf, G. Dennler, M.C. Scharber, C.J. Brabec, P. Schilinsky, and C.N. Hoth, Near IR sensitization of organic bulk heterojunction solar cells: towards optimization of the spectral response of organic solar cells, Adv. Funct. Mater. 20, 338-346 (2010), https://dx.doi.org/10.1002/ adfm.200901473

[7] A. Pivrikas, G. Juška, A.J. Mozer, M. Scharber, K. Arlauskas, N.S. Sariciftci, H. Stubb, and R. Österbacka, Bimolecular recombination coefficient as a sensitive testing parameter for low-mobility solar-cell materials, Phys. Rev. Lett. 94, 176806 (2005), http:// dx.doi.org/10.1103/PhysRevLett.94.176806

[8] M. Koppe, H.-J. Egelhaaf, E. Clodic, M. Morana, L. Lüer, A. Troeger, V. Sgobba, D.M. Guldi,
T. Ameri, and C.J. Brabec, Charge carrier dynamics in a ternary bulk heterojunction system consisting of P3HT, fullerene, and a low bandgap polymer, Adv. Energ. Mater. 3, 949-958 (2013), http://dx.doi. org/10.1002/aenm.201201076

[9] G. Juška, N. Nekrašas, V. Valentinavičius, P. Meredith, and A. Pivrikas, Extraction of photogenerated charge carriers by linearly increasing voltage in the case of Langevin recombination, Phys. Rev. B 84, 155202 (2011), http://dx.doi.org/10.1103/ PhysRevB.84.155202

[10] M.C.Scharber,M.Koppe,J.Gao,F.Cordella,M.A.Loi, P. Denk, M. Morana, H.J. Egelhaaf, K. Forberich, G. Dennler, R. Gaudiana, D. Waller, Z. Zhu, X. Shi, and C.J. Brabec, Influence of the bridging atom on the performance of a low-bandgap bulk heterojunction solar cell, Adv. Mater. 22, 367-370 (2010), http://dx.doi.org/10.1002/adma.200900529

[11]T.M. Clarke, J. Peet, P. Denk, G. Dennler, C. Lungenschmied, and A.J. Mozer, Non-Langevin bimolecular recombination in a silole-based polymer:PCBM solar cell measured by time-resolved charge extraction and resistance-dependent time-of-flight techniques, Energ. Environ. Sci. 5, 5241-5245 (2012), https://dx.doi.org/10.1039/clee02434e

[12]B. Philippa, M. Stolterfoht, R.D. White, M. Velusamy, P.L. Burn, P. Meredith, and A. Pivrikas, Molecular weight dependent bimolecular recombination in organic solar cells, J. Chem. Phys. 141, 054903 (2014), http://dx.doi.org/10.1063/1.4891369

[13]S.S. van Bavel, M. Bärenklau, G. de With, H. Hoppe, and J. Loos, P3HT/PCBM bulk heterojunction solar cells: impact of blend composition and 3D morphology on device performance, $\mathrm{Adv}$. Funct. Mater. 20, 1458-1463 (2010), http://dx.doi. org/10.1002/adfm.200902247

[14] P. Kovacik, H.E. Assender, and A.A.R. Watt, Morphology control in co-evaporated bulk heterojunction solar cells, Sol. Energ. Mater. Sol. Cells 117, 22-28 (2013), http://dx.doi.org/10.1016/j.solmat.2013.05.021

\title{
TRIKOMPONENČIŲ Si-PCPDTBT:P3HT:PCBM SAULĖS ELEMENTŲ KRŪVININKŲ PERNAŠOS SAVYBĖS
}

\author{
J. Važgèla, M. Stephen, G. Juška, K. Genevičius, K. Arlauskas \\ Vilniaus universiteto Kietojo kūno elektronikos katedra, Vilnius, Lietuva
}

\begin{abstract}
Santrauka
Tyrème trikomponentines tūrinès heterosandūros saulès celes ir nustatème jų kompozicijos ịtaką tokiems saulès elementų parametrams kaip naudingumo koeficientas, judris bei rekombinacija. Tirtieji trikomponenčiai sluoksniai buvo sudaryti iš mažo draustinio energijų juostų tarpo polimero poli[2,6-(4,4-bis(2-etil-
\end{abstract}

heksil)ditieno[3,2-b:2,3-d]silol)-alt-4,7-(2,1,3 benzotiadiazolas)] (Si-PCPDTBT), P3HT ir PCBM. Nustatyta, kad, didejant polimero Si-PCPDTBT santykiui, išauga Lanževeno rekombinacijos redukcijos koeficientas. Didžiausi naudingumo koeficientai nustatyti optimizuotuose Si-PCPDTBT:P3HT:PCBM 0.4:0.6:1 sluoksniuose. 